\title{
Efficient production of succinic acid in immobilized fermentation with crude glycerol from Escherichia coli
}

\author{
${ }^{1}$ Nik Nor Aziati, A.A. and ${ }^{2 *}$ Mimi Sakinah, A.M. \\ ${ }^{1}$ Faculty of Engineering Technology, University of Malaysia Pahang (UMP) Kuantan Pahang, Malaysia \\ ${ }^{2}$ Faculty of Chemical Engineering and Natural Resources, University of Malaysia Pahang (UMP) Kuantan
}

Pahang, Malaysia

\begin{abstract}
Article history:
Received: 15 August 2017

Received in revised form: 25

September 2017

Accepted: 28 September 2017

Available Online: 26 October 2017
\end{abstract}

\section{Keywords:}

Succinic acid,

Escherichia coli,

Immobilization,

Glycerol,

Optimization

\section{DOI:}

https://doi.org/10.26656/fr.2017.2(1).156

\begin{abstract}
The increase in the price of commercial succinic acid has necessitated the need for its synthesis from waste materials such as glycerol. Glycerol residue is a waste product of Oleochemical production which is cheaply available and a very good source of carbon. The use of immobilized cells can further reduce the overall cost of the production process. This study primarily aims to produce succinic acid from glycerol residue through the use of immobilized Escherichia coli in a batch fermentation process. The parameters which affect bacterial fermentation process such as the mass substrate, temperature, inoculum size and duration of fermentation were screened using One-Factor-At-a-Time (OFAT) method. The result of the screening process shows that a substrate (glycerol) concentration of $30 \mathrm{~g}$, inoculum size $20 \% \mathrm{v} / \mathrm{v}$, and time $4 \mathrm{~h}$ produced the maximum succinic acid concentration of $117.99 \mathrm{~g} / \mathrm{L}$. The immobilized cells were found to be stable as well as retain their fermentative ability up to the $6^{\text {th }}$ cycle of recycling, thereby presenting as an advantage over the free cell system. Therefore, conclude that using immobilized cells can contribute immensely to the cost-effective production of succinic acid from glycerol residue.
\end{abstract}

\section{Introduction}

According to Isar et al. (2006a) succinic acid which is also called amber or butanedioic acid is one of the groups of acids in the dicarboxylic acid family with a molecular formula of $\mathrm{C}_{4} \mathrm{H}_{6} \mathrm{O}_{4}$. It was first purified from amber in 1546 by Georgius Agricola and since then has mainly been sourced from the action of microbes on some specific substrates. There are many industrial applications of succinic acid such as in the food, cosmetic, and pharmaceutical industries (Zeikus et al., 1999). Across the world, the production of succinic acid from residues such as glycerol has attracted much interest due to the growing trend in the generation of energy from renewable sources. Through a process of pre-treatment and fermentation, a reasonable amount of succinic acid can be produced from glycerol in an environmentally friendly way. There is a possibility of replacing the production of succinic acid from chemicals with the eco-friendly approaches in the near future.

There is a current effort in Malaysia towards the conversion of the huge waste from the oil palm industry into bioenergy sources. Malaysia as at 2008 was ranking second in the world list of palm oil producers with reported 17.7 million tons or about $41 \%$ of the total world palm oil supply. Similarly, palm kernel oil is basically used during Oleochemical production through the process of trans-esterification. Through this process, there is a massive generation of waste products such as glycerol (Ooi et al., 2001). Been that glycerol is one of the chief waste products of the Oleochemical industries due to the abundance of distillation plants in Malaysia, there is a great potential of turning this industrial waste into a huge source of bioenergy (Luo et al., 2011).

However, glycerol residue is made up of free fatty acids and to make it suitable for bioconversion, there is a need for pretreatment through esterification (Hayyan et al., 2011), followed by trans-esterification using an alkali catalyst for onward conversion to glycerol. Meanwhile, agricultural wastes have attracted less attention in the area of pre-treatment and as a consequence, very limited data exist for pre-treatment of Oleochemical wastes. In view of all these, this study focuses on the production of succinic acid from glycerol through the use of 
immobilized bacterial cells in a simple batch fermentation process. During the study, the effect of some factors such as the inoculum densities, the time (duration) of fermentation, and the amount (mass) of the substrate on the production of succinic acid will be studied. The pattern of succinic acid production, its characteristics and fermentative characteristics will be explained during the course of the study. The conversion of glycerol into higher value products through anaerobic fermentation was also discussed.

\section{Materials and methods}

\subsection{Preparation of crude glycerol}

The pretreatment of the glycerol residue obtained from Emery Oleo chemicals Sdn. Bhd involved many steps. Dilution of the residue was the first step, followed by the filtration, neutralization, separation, evaporation and decanting steps (Ooi et al., 2001). Sulphuric acid, sodium hydroxide, and silicon oil bath were used for the pretreatment of the glycerol residue (Lozano et al., 1996; Ooi et al., 2001). The next step was the alkali-catalysed trans-esterification which was the removal of the residue salts from the glycerol-rich layer. The recovered solution was neutralized by the addition of $5 \mathrm{M} \mathrm{NaOH}$ solution until the $\mathrm{pH}$ was 7 . The solution was then left for a short while before filtering for the elimination of the precipitated salt. Having completed the process of separation using the rotary evaporator, the residual water was removed by transferring the solution to another container. The temperature of the oil bath during the extraction process was maintained at $105^{\circ} \mathrm{C}$ as the process proceeded for $2 \mathrm{~h}$ (Ooi et al., 2001).

\subsection{Bacterial cell culturing}

E. coli strain $\mathrm{K}-12$ was used in the free and immobilized states during the study. The stock culture was grown and maintained on Luria-Bertani agar medium (LB) and agar slants, respectively at $37^{\circ} \mathrm{C}$ before being used further in the study (Huang et al., 2002). A colony of the organism was seeded into a 50 $\mathrm{mL}$ of the medium (supplemented with Trypton $10 \mathrm{~g} / \mathrm{L}$, Yeast extract $5 \mathrm{~g} / \mathrm{L}$, and glycerol $5 \mathrm{~g} / \mathrm{L}$ ) in a $100 \mathrm{~mL}$ flask. The supplemented medium containing the organism was incubated at $37^{\circ} \mathrm{C}$ and the optical density (OD) monitored in a spectrophotometer until a value of 0.4 was reached at $550 \mathrm{~nm}$ wavelength. A volume of the culture medium was taken and centrifuged at $10000 \mathrm{~g}$ to obtain the cell pellets. The pellets were separated from the medium and the free cells washed severally before been used to inoculate the medium $(\mathrm{OD}$ at inoculation $=$ 0.05 at $550 \mathrm{~nm}$ ). For the immobilized cells, the washed free cells were further entrapped in sodium alginate.

\subsection{Immobilization of the bacterial cells}

The cells were immobilized in the following way: The cells already pre-cultured in $250 \mathrm{~mL}$ of LB broth was centrifuged at $10,000 \mathrm{rpm}$ for $10 \mathrm{~min}$ at $4^{\circ} \mathrm{C}$ to get the pellets of the cells (Agarwal et al., 2005). The cell pellets were further mixed with $250 \mathrm{~mL}$ of sodium alginate solution at a concentration of $2 \% \mathrm{v} / \mathrm{v}$. The mixture was homogenized by thorough mixing for about $1 \mathrm{~h}$ (Vintila et al., 2009; Zhao and Xia, 2010). Having achieved homogeneity, the cell-sodium-alginate mixture was dropped into a solution of $0.1 \mathrm{M}$ Calcium chloride $\left(\mathrm{CaCl}_{2}\right)$ with the aid of a syringe at a fixed syringe-to$\mathrm{CaCl}_{2}$ solution surface height (Heipieper et al., 1991; Vintila et al., 2009; Malvessi et al., 2010). The $\mathrm{CaCl}_{2}$ solution was continuously stirred throughout the period of bead formation. After forming the beads, the $0.1 \mathrm{M}$ $\mathrm{CaCl}_{2}$ solution was substituted with a weaker solution $\left(0.05 \mathrm{M} \mathrm{CaCl}_{2}\right)$ and then allowed to be in contact with the beads for about $12 \mathrm{~h}$ to harden up. After the $12 \mathrm{~h}$ of hardening, the beads were collected and rinsed severally with sterile normal saline $(0.85 \% \mathrm{NaCl})$ solution in order to eliminate the untrapped cells and the free ions of $\mathrm{CaCl}_{2}$ (Heipieper et al., 1991;Kosseva et al., 1998; Zhou et al., 1998; Zhao and Xia, 2010).

\subsection{Modification of the fermentation condition}

Into $50 \mathrm{~mL}$ flasks containing varying medium compositions as shown in Table $1,20 \% \mathrm{v} / \mathrm{v}$ active $E$. coli suspensions were aseptically added. The content of the flasks with a $\mathrm{pH}$ of 6.5 was incubated in an incubator at $37^{\circ} \mathrm{C}$. The method used for the culturing was similar to a solid state fermentation process where solid substrates are used, but here, liquid slurry (treated glycerol) was used as the substrate. The culture was then centrifuged for $10 \mathrm{~min}$ at $10000 \mathrm{rpm}$ to obtain the supernatant that was used to assay for the succinic acid concentration using the HPLC (Ng and Yang, 2016).

Table 1. The data for the OFAT screening of pre-treatment parameters

\begin{tabular}{cccccc}
\hline Variable/Parameters & & & & & \\
\hline Time (hour) & 0 & 2 & 4 & 6 & 8 \\
Mass substrate (gram) & 10 & 20 & 30 & 40 & 50 \\
Inoculums density (\%) & 10 & 15 & 20 & 25 & 30 \\
\hline
\end{tabular}

\subsection{E. coli growth profiling (kinetics)}

Batch fermentations were carried out to profile the growth kinetics of the E. coli strain K-12. A medium containing $10 \%(\mathrm{v} / \mathrm{v})$ of the organism was prepared and 
incubated at $37^{\circ} \mathrm{C}$ for $24 \mathrm{~h}$. Aliquots of samples were withdrawn at $2 \mathrm{~h}$ interval for OD measurement at 550 $\mathrm{nm}$, succinic acid, and glycerol concentrations.

\subsection{Beads’ stability study}

For the beads stability test at different temperatures, the pour plate method was used to assess the activity of the bacterial cells. The stability of the beads was checked for 7 days on a daily sampling basis at freezer $\left(-4^{\circ} \mathrm{C}\right)$ and incubator $\left(37^{\circ} \mathrm{C}\right)$ temperatures. The samples collected daily were used to count for total bacterial count using the total plate method.

\section{Results and discussion}

\subsection{Growth profile of E. coli K-12}

The growth profile of the $E$. coli strain $K-12$ was studied through its ability to ferment the substrate in a free state. The growth profile of the E. coli cultured in pre-treated glycerol with carbon supplements under the anaerobic condition is shown in Figure 1. The growth profile was studied with about $20 \%$ of the working inoculum volume by measuring the succinic acid concentration and culture OD using the HPLC and the $\mathrm{UV}-\mathrm{V}$ is spectrophotometer. The OD, measured with a transmission densitometer, represents the actual lightblocking ability of the material. From the results, it was observed that the growth profile tallied with the succinic acid concentration as well as the OD of the medium during the fermentation process. Higher cell activity manifested in increased concentration of succinic acid and the OD of the medium.

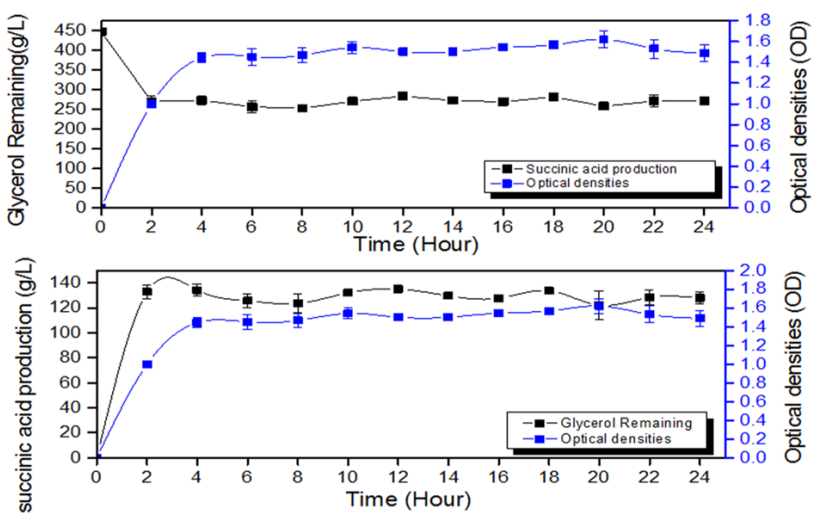

Figure 1. The growth profile of the E. coli strain K-12 and the glycerol remining after fermentation

The result as shown portrayed a correlation between the fermentation times (duration) and the concentration of succinic acid. Increase in the fermentation time leads to increase in the concentration of succinic acid and consequently increase in the cell concentration within the fermentation medium. The initial OD after $2 \mathrm{~h}$ of fermentation was approximately 0.998, but as the cells multiply and grow, the OD increased to 1.379 after $10 \mathrm{~h}$, though there was a gradual decline after $12 \mathrm{~h}$, showing a reduction in cell concentration due to cell death. There was a rapid increase in the cell growth during the exponential phase as manifested in the OD value of 1.355 after $6 \mathrm{~h}$.

The results for the residual glycerol after fermentation are also shown in Figure 1. After $6 \mathrm{~h}$ of fermentation, the residual glycerol concentration (remaining) was $256.224 \mathrm{~g} / \mathrm{L}$ while there was a gradual increase in the succinic acid concentration to about $(101.174 \mathrm{~g} / \mathrm{L})$. This is evidence that the bacterial growth has a direct correlation with the time of fermentation. The succinic acid concentration after $24 \mathrm{~h}$ of profiling was $102.932 \mathrm{~g} / \mathrm{L}$, a slight increase compared to the concentration after $6 \mathrm{~h}$. This is an indication of the active growth of the bacteria in the medium with a resultant increase in succinic acid production.

In order to explain the growth behavior of the organism from the profile curve, the Monod equation was used. This equation also demonstrates the kinetics of the microbial utilization of the substrate efficiently. The Monod equation determines the relation between the bacterial growth and the residual substrate in the system with a single growth limiting substrate as shown in Equation1.

$$
\mu=\left(\frac{\mu \max s}{K(S)}+S\right)
$$

where $\mu$ is the specific growth rate $\left(\right.$ time $\left.^{-1}\right), \mu_{\max }$ is the maximum growth rate $\left(\right.$ time $\left.^{-1}\right), \mathrm{S}$ is the substrate concentration $(\mathrm{mg} / \mathrm{L})$ and $\mathrm{K}_{\mathrm{s}}$ is the half saturation coefficient which is equal to the concentration of the rate -limiting substrate when the specific rate of growth is equal to one-half of the maximum $(\mathrm{mg} / \mathrm{L})$. The equation stipulates that an increase in the substrate will lead to increase in microbial growth which satisfied the collision frequency theory for microbial growth. When the concentration of substrate is high, the equation approaches a zero order, making the reaction rate to be independent of the concentration of substrate and maintaining a maximum constant value.

$E$. coli have been shown to actively grow even in media with a minimum concentration of nutrients for the growth of other bacteria. The optimum growth conditions like the temperature, salt concentration, $\mathrm{pH}$, and source of nutrient vary based on the species of $E$. coli. There must be a source of carbon in the medium to support the growth of E. coli. Essential elements such as magnesium, phosphorus, nitrogen, and sulphur are 
usually sourced from the carbon source. For the synthesis of some basic cellular components, glycerol, sugars and some salts are usually used as bacterial carbon source. There are other factors such as the $\mathrm{pH}$ and temperature which contributed to the enhanced succinic acid production other than the carbon source although glycerol as the carbon source enhanced the production rate of succinic acid (Lee et al., 2000; Piattoni et al., 2013; Simone, 2017). Nitrogen source is a combination of ingredients which promote the growth of bacterial cells within the culture medium.

Tryptone is the commonest nitrogen source used to promote enzymatic activities. It usually provides basic amino acids which support the growth of bacteria but other ingredients such as yeast extract provide vitamins and other trace elements which contained a lot of organic compounds that support the growth of $E$ coli. Sodium chloride, which is an additive, supports transport mechanisms and maintains osmotic balance through the provision of ions. The $\mathrm{pH}$ and temperature of the medium are vital parameters which need to be maintained for efficient growth of $E$. coli. The optimal temperature for effective growth of $E$. coli is approximately $37^{\circ} \mathrm{C}$ while the optimum $\mathrm{pH}$ is within the range of 6-7. At higher temperatures, there could be no growth of the organism. A reasonable amount of succinic acid can be produced in $E$. coli when the fermentation process is performed at $37^{\circ} \mathrm{C}$ for $24 \mathrm{~h}$. The effect of temperature on the enzymes involved in succinic acid production inversely affects the succinic acid production rate well.

\subsection{Optimization of the process parameters using OFAT}

\subsubsection{Effect of substrate concentration}

Pretreated glycerol residue was used as the substrate for the production of succinic acid. Glycerol concentration, been the carbon source significantly affected the production of succinic acid. Different concentrations of carbon source affect the growth rate of microorganisms as well as the product of their metabolic activities. Different concentrations of glycerol were studied for possible effect on succinic acid production using E. coli (Lu et al., 2013). Based on Figure 2, there is a direct correlation between the concentration of substrate and the rate of succinic acid production.

The rate of succinic acid production progressively increased with increase in substrate concentration until at $30 \mathrm{~g} / \mathrm{L}$ of the substrate when the maximum yield of succinic acid (117.99 g/L) was achieved (Tao et al., 2015). Increasing the concentration of substrate to $40 \mathrm{~g} / \mathrm{L}$ resulted in a gradual decline in the concentration of succinic acid. The relation between the substrate concentration and the rate of chemical or enzymatic reaction is best explained by the Monod equation shown in Equation (2).

$$
\mu=\mu \frac{\max (K s+s)}{s}
$$

where $\mu$ is the specific growth, $\mu$ max=maximum growth rate, $\mathrm{S}=$ substrate concentration, and $\mathrm{Ks}=$ substrate concentration at $\mu=0.5 \mu \max$. The formulation model is described based on the saturation kinetics premise where the rate of microbial growth depends on the concentration of the limiting nutrient as described by two constants: the maximum growth rate $(\mu \max )$ and the limitation constant $\left(\mathrm{K}_{\mathrm{S}}\right)$. Additionally, the growth of an organism depends on the rate of substrate uptake which also directly depends on the concentration of substrate in the medium.

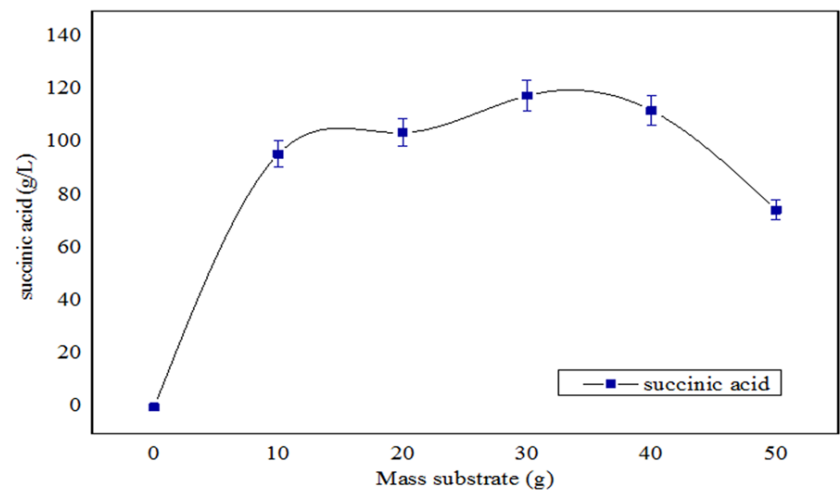

Figure 2. Effect of substrate concentration on succinic acid production

Cell growth is linearly related to the substrate concentration as shown in Equation 2 where the relationship between substrate concentration and uptake is expressed. For heterotrophic organisms, the source of carbon plays a crucial role but for anaerobic fermentation, one of the factors which either limit or enhance the growth rate of organisms is the rate of anaerobic uptake and the rate of energy generation from the organic substrate. Growth is been controlled through the limitation of the nutrient uptake, a situation known as energy limited growth (Çelik et al., 2008; Mantzouridou et al., 2008).

The effect of substrate concentration on the rate of product formation has been studied by Khanna et al. who made use of biodiesel sourced from crude glycerol to produce n-butanol using immobilized Clostridium pasteurianum. The study concluded that different substrate concentrations had effect on different products. A substrate concentration of $25 \mathrm{~g} / \mathrm{L}$ favored the production of butanol, 1-2-Propanediol, and ethanol, while a concentration of $10 \mathrm{~g} / \mathrm{L}$ favored the production 
of propanediol; $150 \mathrm{~g} / \mathrm{L}$ favored ethanol production (Khanna et al., 2013). The kinetics of substrate and product inhibition during the production of succinic acid has been studied by Lin et al. (2008) using Actinobacillus succininogenes. They used glucose as the carbon source and from the outcome, it was observed that the substrate and product inhibition had a significant effect on the cell growth as well as succinic acid production (Lin et al., 2008). Similarly, Ghorbani et al. (2011) studied the effect of various substrate concentrations on the production of ethanol from molasses using immobilized Saccharomyces cerevisiae. The results showed that the substrate concentration had a significant effect on the rate of ethanol production (Ghorbani et al., 2011).

The results of our study also proved that increasing the concentration of glycerol also increased the rate of succinic acid production up to a level before it started exhibiting its inhibitory effect (Tao et al., 2015). This inhibition was likely due to the high concentration of the treated glycerol residue which led to substrate saturation. At high substrate concentration, there is the tendency of having an effect on the reaction in the phase solution where the rate of reaction is slowed. At this level of substrate saturation, all the substrates in the medium are been supplied in excess which might turn to be toxic to the organisms and results in a low rate of conversion (Lin et al., 2008). Another effect of an increased substrate concentration is partial cell dehydration which results in reduced cell growth (Heipieper et al., 1991). In our study, substrate inhibition was observed when the concentration of glycerol was raised to $40 \mathrm{~g} / \mathrm{L}$ (Lin et al., 2008).

\subsubsection{Effect of inoculum size}

Inoculum size is of the major factors that affect the rate of biological reactions. The effect of various inoculum sizes on the production of succinic acid is shown in Figure 3. In this study, it was aimed to observe the relationship between the inoculum size and succinic acid production. It can be seen from Figure 3 that the optimum inoculums size for optimum succinic acid production was $20 \% \mathrm{v} / \mathrm{v}$ which yielded a succinic acid concentration of $102.30 \mathrm{~g} / \mathrm{L}$. Having entrapped the bacteria in sodium alginates, it was observed that the $E$. coli have different growth rates which manifested in different production yields at different inoculum sizes. The graph also showed a decrease in the concentration of succinic acid production $(100.90 \mathrm{~g} / \mathrm{L})$ as the size of the inoculum was reduced to $10 \% \mathrm{v} / \mathrm{v}$. When the size of the inoculum was increased to $30 \% \mathrm{v} / \mathrm{v}$, the was a visible decrease in the succinic acid concentration $(93.79 \mathrm{~g} / \mathrm{L})$ which could be due to the fast utilization of available nutrients in the medium as a result of increased cell number with accompanied cell starvation and death.

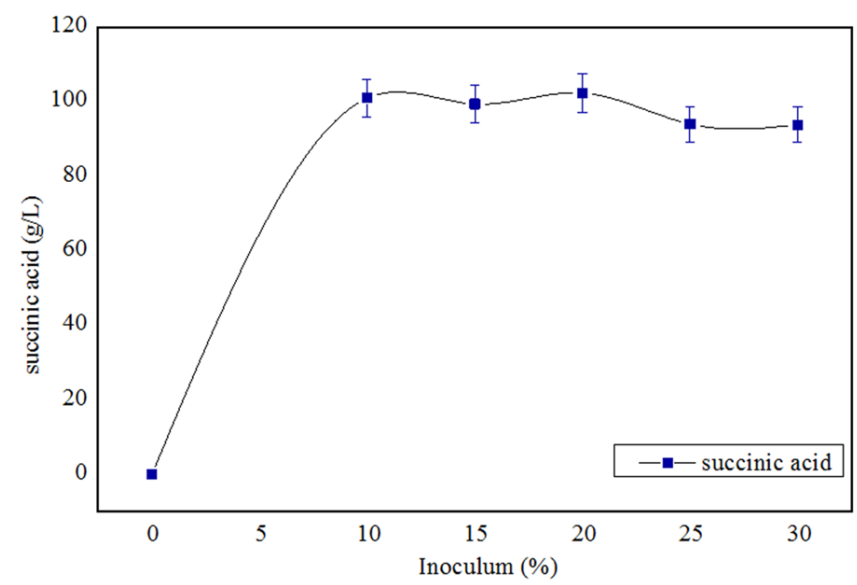

Figure 3. Effect of inoculum size on succinic acid production

In an ideal situation, cell number ought to be proportional to growth rate as explained in Equation 3, 4, and 5 which show the relationship between the substrate, $(\mathrm{X})$, cell number $(\mathrm{N})$, growth rate $(\mu)$ and time $(\mathrm{t})$. An increase in the cell number $(\mathrm{N})$ or biomass $(\mathrm{X})$ definitely leads to increase in the growth rate. Increased growth rate implies increased succinic acid production in our case. There could be a decrease in production as a result of a combination of factors such as reduced E. coli activity due to excess number of cells as well as nutrient exhaustion in the medium.

$$
\begin{aligned}
& X(t)=\mu(t) \cdot X(t) \\
& N(t+t d)=2 \cdot N(t) \\
& t d=\ln 2 / \mu
\end{aligned}
$$

The concentration of biomass according to the equations is equal to the rate of growth and the rate of succinic acid production as well. Equation 5 shows the doubling time (td) of the cell population which literally shows the required time for the cells to double in concentration, which has a direct relationship with the specific growth rate. Various studies have reported the use of free or immobilized cells during fermentation processes. Ercan et al. (2013) optimized ethanol production using entrapped yeast cells. Their results using 5\% entrapped yeast cells showed that the number of beads in the fermentation medium had an effect on the ethanol production rate. The number of cells entrapped in the beads also has a significant effect on the production of the product (Ercan et al., 2013).

\subsubsection{Effect of time (duration of fermentation)}

The duration of fermentation was studied to 
determine the maximum length of time required for the optimum conversion of the glycerol to succinic acid. The result of the effect of fermentation duration is shown in Figure 4. It was observed from the study that the maximum succinic acid concentration $(110.20 \mathrm{~g} / \mathrm{L})$ was achieved after $4 \mathrm{~h}$ of fermentation and tends to decrease as the time was increased. The decrease was as a result of $E$. coli beginning a new growth phase which required moments of idle activity after $4 \mathrm{~h}$. During the study of the growth profile of the organism, different growth rates were observed at the different stages of growth (lag phase, acceleration phase, and exponential growth phase) ( Panesar et al., 2007; Zhao and Xia, 2010).

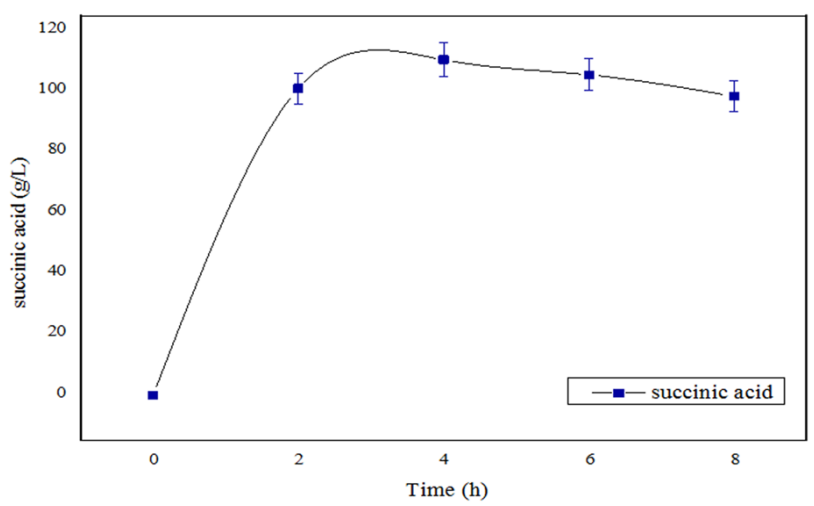

Figure 4. Effect of time on succinic acid production

The bacterial growth at the exponential phase can be expressed in Equation (6) as far as all the cells have acclimatized to the medium and are able to divide and multiply irrespective of the availability of nutrients or inhibitors in the medium. There is need to consider other stages of the growth profile of the organism since the growth phase did not end with the lag phase but just the beginning of fermentation.

$$
X(t)=X 0 . e \mu \max . t
$$

After $6 \mathrm{~h}$, there was a decrease in the growth of the organism which is characteristic of the deceleration or retardation phase where there is no longer the possibility of unlimited growth due to the exhaustion of nutrients and accumulation of toxins in the medium. After this phase, growth rate becomes a function of nutrient and product concentration as well as the time. There could be morphological changes around the cell due to the persistent increase in cell population but the specific growth rate at certain points tends to decline with time. At a point, the specific growth rate becomes zero due to the exhaustion of nutrients in the media. There are certain products like intracellular materials which can still permit the multiplication of some cells while others die. The last phase of growth is where the specific growth rate becomes negative due to the inability of the cells to maintain their physiology activities.

Several studies have been reported on the effect of time on immobilized cells. Ghorbani et al. (2011) used immobilized cells during the production of ethanol from cane molasses. The results of the study showed that time had a visible effect on the ethanol production with reported retention times of 5.21, 6.94, 10.42, and 15.63 h. Furthermore, Zhao et al. (2010) used immobilized cells when they studied the production of ethanol from the hemicellulosic hydrolysate of corn stover. The results proved that fermentation using immobilized cells was more effective at a prolonged time of 72 . Additionally, Khanna et al. (2013) used glycerol from biodiesel to produce n-ethanol through immobilization technique and reported the maximum n-butanol yield within $120 \mathrm{~h}$. Fermentation with immobilized $E$. coli yielded a high succinic acid concentration after $6 \mathrm{~h}$ of fermentation. From Their studies, these factors were screened to establish the optimum range of values to be used during the statistical optimization of the process using RSM.

\subsection{Immobilized cells stability}
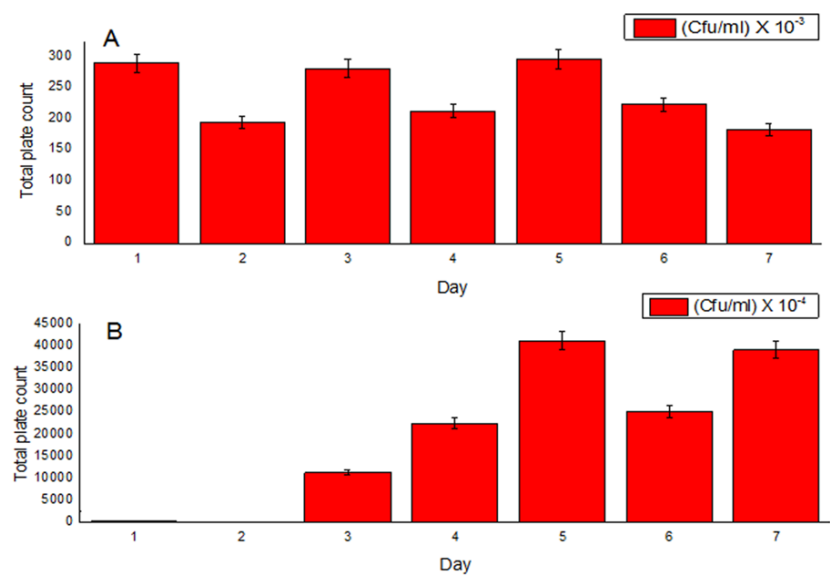

Figure 5. Bacterial cell concentration from day one to day seven (a) $-4{ }^{\circ} \mathrm{C}$ (b) $37{ }^{\circ} \mathrm{C}$

Investigations were carried out to ascertain the temperature stability of the immobilized $E$. coli at a low $\left(-4^{\circ} \mathrm{C}\right)$ temperature since it has been reported that immobilization confers protection to cells when exposed to harsh environments. From the results shown in Figure 5 , the bacteria concentration in the beads on the first day $\left(292 \times 10^{3} \mathrm{CFU} / \mathrm{mL}\right)$ was maintained until the $2^{\text {nd }}$ day when it decreased to $283 \times 10^{3} \mathrm{CFU} / \mathrm{mL}$. On the next check on day 5 , the bacterial concentration increased to $298 \times 10^{3} \mathrm{CFU} / \mathrm{mL}$ due to the completion of the exponential phase where most of the bacteria have multiplied. After the 5th day, there was a decline in the bacterial concentration due to several factors which must have affected the survival of the bacteria cells. Fresh cell beads are recommended here to be used on the first day of fermentation and could be stored for up to 5 days for 
further use. After 5 days, cell performance may decrease due to a decrease in cell number.

Although there are changes in the concentration of cells within the beads after storage at low temperature for 7 days, morphological changes were not observed even after 7 days of storage. Also, there was an insignificant change in the concentration of succinic acid produced from cells stored at low temperature for varying number of days. This shows that storage at low temperature might have a significant effect on the bacteria number but quite insignificant on the bacteria performance. The storage stability of a mixed Cryptococcus elinovii H1and Pseudomonas putida P8 culture adsorbed in activated carbon was studied by Morsen and Rehm and the results showed a little variance in the results of the first and second fermentation processes after storage (Heipieper et al., 1991). Similarly, Chavarri et al. (2010) observed the stability of microencapsulated probiotic bacteria with or without quercetin at $4^{\circ} \mathrm{C}$ during 4 weeks of storage. The results presented a significant difference in stability of the organism at the studied conditions which were also associated with significant variation in the growth rate.

To further the stability check of the immobilized bacteria, the beads were stored at $37^{\circ} \mathrm{C}$ for one week with a periodical count of the bacterial number. The results show a linear relationship between bacterial activities and period of incubation due to the exposure of the organism to its ideal temperature. Studies were also extended to storage at $50^{\circ} \mathrm{C}$ where no growth was observed, thereby concluding that storage at low temperature has mild effect on the bacterial growth but not on the activity; while storage at $37^{\circ} \mathrm{C}$ favoured both bacterial growth and activity; but at $50^{\circ} \mathrm{C}$, no form of bacterial activity or growth was supported due to denaturation and death of the bacteria. The bacterial enzyme activities via the reverse TCA cycle were optimum at $37^{\circ} \mathrm{C}$. It is noted that due to genetic makeup, different bacterial species have different levels of tolerance to temperature, mostly ranging between 20 to $30^{\circ} \mathrm{C}$. Some species prefer higher temperatures (50 to $55^{\circ} \mathrm{C}$ ) while some prefer lower temperatures (15 to $20^{\circ}$ C). Furthermore, the production of lactic acid by the use of bacteria is mostly favored at 18 to $22^{\circ} \mathrm{C}$. The Leuconostoc species that are mostly involved in fermentation processes perform better a temperature range of 18 to $22^{\circ} \mathrm{C}$ while Lactobacillus species prefer a temperature of $22^{\circ} \mathrm{C}$.

The production of desired products through bacterial fermentation is mostly affected indirectly when the organism is exposed to the unfavorable environment. Gonzalez et al. (2006a) reported using E. coli at $37^{\circ} \mathrm{C}$ during anaerobic fermentation while Isar et al. (2006b) used E. coli to produce succinic acid at $39^{\circ} \mathrm{C}$. These are the manifestations of variations in the temperature requirement of different species of organism.

\subsection{Immobilized cells reusability}

One of the main benefits of the cell immobilization techniques is the reusability of the cells which is not possible with the free cells. The immobilization process allows for easy separation of the cells from the slur for further use. The immobilized cell beads can be reused severally with little or no changes in the output of the process after about 6 cycles. It promotes environmental sustainability because there is no much waste of resources and time. It also ensures the retention of a good number of cells within the fermentation environment. A common example of the immobilization technique is the production of butanol through the $\mathrm{ABE}$ fermentation process, where cell recycling and immobilization increased the cell density and the productivity of the reactor (Cunha et al., 2007). In this study, the immobilized cells were recycled for 6 rounds of the fermentation process and from the results shown in Figure 6, the high succinic acid concentration was still maintained after the $6^{\text {th }}$ round of fermentation.

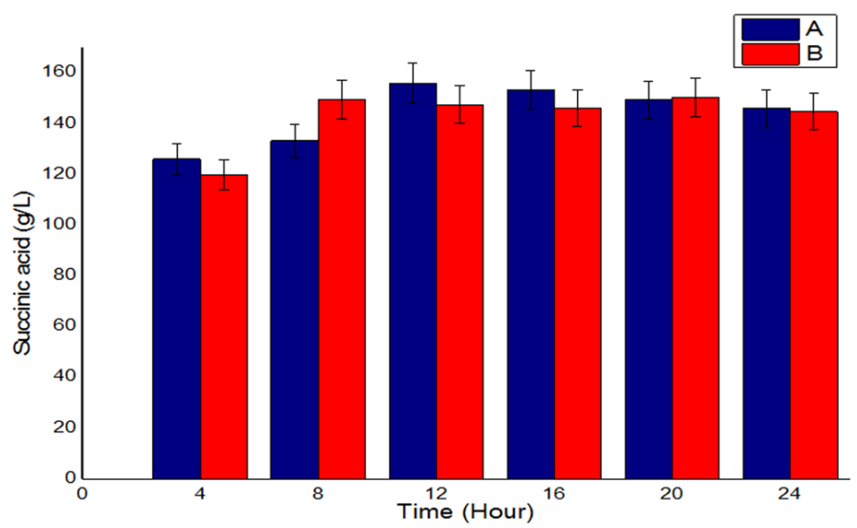

Figure 6. Succinic acid production after (A) first and (B) second rounds of recycling immobilized cells

Although there was a slight difference between the outcome of the first and second fermentation process, this difference was not really significant since the yield was still high when compared to the first round with fresh beads. The level of succinic acid production was relatively maintained on the high side until the sixth cycle though there were slight variations in values. It can, therefore, be concluded that immobilizing E. coli can be a better option during the production of succinic acid with added advantages of easy handling and reusability. 


\section{Conclusion}

There were pronounced effects of time, inoculum size, and substrate concentration, thereby prompting paying more attention to these factors when using the immobilized cells for bioproduction. From the plate count study, immobilized cells have good stability at a temperature of -4 and $37^{\circ} \mathrm{C}$ but depend on the microorganism. From the outcome of the succinic acid production study, we can conclude that immobilized $E$. coli can be used to produce succinic acid using glycerol residue as the sole source of carbon, with the added advantage of being able to be reused severally as well as being easy to handle.

\section{References}

Agarwal, L., Isar, J. and Saxena, R.K. (2005). Rapid screening procedures for identification of succinic acid producers. Journal of Biochemical and Biophysical Methods, 63(1), 24-32. https:// doi.org/10.1016/j.jbbm.2005.01.002

Çelik, E., Ozbay, N., Oktar, N. and Çalık. (2008). Use of Biodiesel Byproduct Crude Glycerol as the Carbon Source for Fermentation Processes by Recombinant Pichia pastoris Use of Biodiesel Byproduct Crude Glycerol as the Carbon Source for Fermentation Processes by Recombinant Pichia pastoris. Industrial and Engineering Chemistry Research, 47 (9), 2985-2990. https://doi.org/10.1021/ie071613o

Cunha, M.A.A., Rodrigues, R.C.B., Santos, J.C., Converti, A. and Silva, S.S.Da. (2007). Repeatedbatch xylitol bioproduction using yeast cells entrapped in polyvinyl alcohol-hydrogel. Current Microbiology, 54(2), 91-96. https://doi.org/10.1007/ s00284-005-0465-4

Ercan, Y., Irfan, T. and Mustafa, K. (2013). Optimization of ethanol production from carob pod extract using immobilized Saccharomyces cerevisiae cells in a stirred tank bioreactor. Bioresource Technology, 135, 365-371. https://doi.org/10.1016/ j.biortech.2012.09.006

Ghorbani, F., Younesi, H., Esmaeili Sari, A. and Najafpour, G. (2011). Cane molasses fermentation for continuous ethanol production in an immobilized cells reactor by Saccharomyces cerevisiae. Renewable Energy, 36(2), 503-509. https:// doi.org/10.1016/j.renene.2010.07.016

Hayyan, A., Alam, M.Z., Mirghani, M.E.S., Kabbashi, N.A., Hakimi, N.I.N.M., Siran, Y.M. and Tahiruddin, S. (2011). Reduction of high content of free fatty acid in sludge palm oil via acid catalyst for biodiesel production. Fuel Processing Technology, 92(5), 920-924. https://doi.org/10.1016/ j.fuproc.2010.12.011

Heipieper, H.J., Keweloh, H. and Rehm, H.J. (1991). Influence of phenols on growth and membranepermeability of free and immobilized Escherichia coli. Applied and Environmental Microbiology, 57 (11), 1213-1217.

Huang, Y.L., Wu, Z., Zhang, L., Ming Cheung, C. and Yang, S.T. (2002). Production of carboxylic acids from hydrolyzed corn meal by immobilized cell fermentation in a fibrous-bed bioreactor. Bioresource Technology, 82(1), 51-59. https:// doi.org/10.1016/S0960-8524(01)00151-1

Isar, J., Agarwal, L., Saran, S. and Saxena, R.K. (2006a). A statistical method for enhancing the production of succinic acid from Escherichia coli under anaerobic conditions. Bioresource Technology, 97(13), 14431448. https://doi.org/10.1016/j.biortech.2005.07.014

Isar, J., Agarwal, L., Saran, S. and Saxena, R.K. (2006b). Succinic acid production from Bacteroides fragilis: Process optimization and scale up in a bioreactor. Anaerobe, 12(5-6), 231-237. https:// doi.org/10.1016/j.anaerobe.2006.07.001

Khanna, S., Goyal, A. and Moholkar, V.S. (2013). Production of n-butanol from biodiesel derived crude glycerol using Clostridium pasteurianum immobilized on Amberlite. Fuel, 112, 557-561. https://doi.org/10.1016/j.fuel.2011.10.071

Kosseva, M., Beschkov, V., Kennedy, J.F. and Lloyd, L.L. (1998). Malolactic fermentation in Chardonnay wine by immobilised Lactobacillus casei cells. Process Biochemistry, 33(8), 793-797. https:// doi.org/10.1016/S0032-9592(98)00049-1

Lee, P.C., Lee, W.G., Lee, S.Y., Chang, H.N. and Chang, Y.K. (2000). Fermentative Production of Succinic Acid from Glucose and Corn Steep Liquor by Anaerobiospirillum succiniciproducens. Biotechnology and Bioprocess Engineering, 5, 379381. https://doi.org/10.1007/BF02942216

Lin, S.K.C., Du, C., Koutinas, A., Wang, R. and Webb, C. (2008). Substrate and product inhibition kinetics in succinic acid production by Actinobacillus succinogenes. Biochemical Engineering Journal, 41 (2), 128-135. https://doi.org/10.1016/ j.bej.2008.03.013

Lozano, P., Chirat, N., Graille, J. and Pioch, D. (1996). Measurement of free glycerol in biofuels. Fresenius Journal of Analytical Chemistry, 354, 319-322. https://doi.org/10.1007/s0021663540319 
Lu, L.P., Zhang, B.B. and Xu, G.R. (2013). Efficient conversion of high concentration of glycerol to Monacolin $\mathrm{K}$ by solid-state fermentation of Monascus purpureus using bagasse as carrier. Bioprocess and Biosystems Engineering, 36(3), 293 299. https://doi.org/10.1007/s00449-012-0784-3

Luo, G., Talebnia, F., Karakashev, D., Xie, L., Zhou, Q. and Angelidaki, I. (2011). Enhanced bioenergy recovery from rapeseed plant in a biorefinery concept. Bioresource Technology, 102(2), 14331439. https://doi.org/10.1016/j.biortech.2010.09.071

Malvessi, E., Carra, S., da Silveira, M.M. and Ayub, M.A.Z. (2010). Effect of substrate concentration, $\mathrm{pH}$, and temperature on the activity of the complex glucose-fructose oxidoreductase/glucono-lactonase present in calcium alginate-immobilized Zymomonas mobilis cells. Biochemical Engineering Journal, 51 (1-2), 1-6. https://doi.org/10.1016/j.bej.2010.04.003

Mantzouridou, F., Naziri, E. and Tsimidou, M.Z. (2008). Industrial gycerol as a supplementary carbon source in the production of beta-carotene by Blakeslea trispora. Journal of Agricultural and Food Chemistry, 56, 2668-2675. https://doi.org/10.1021/ jf703667d

Ng, C.H. and Yang, K.-L. (2016). Triphasic esterification of butanol and butyric acid in fermentation media. Process Biochemistry, 53, 194 200. https://doi.org/10.1016/j.procbio.2016.12.010

Ooi, T.L., Yong, K.C., Dzulkefly, K., Wan Yunus, W.M.Z. and Hazimah, A.H. (2001). Crude Glycerine Recovery From Glycerol Residue Waste From a Palm Kernel Oil Methyl Ester Plant. Journal of Oil Palm Research, 13, 16-22.

Panesar, R., Panesar, P.S., Singh, R.S. and Bera, M.B. (2007). Applicability of alginate entrapped yeast cells for the production of lactose-hydrolyzed milk. Journal of Food Process Engineering, 30(4), 472$484 . \quad$ https://doi.org/10.1111/j.17454530.2007.00127.x

Piattoni, C.V., Figueroa, C.M., Asención Diez, M.D., Parcerisa, I.L., Antuña, S., Comelli, R.A., Guerrero, S.A., Beccaria, A.J. and Iglesias, A. Á. (2013). Production and characterization of Escherichia coli glycerol dehydrogenase as a tool for glycerol recycling. Process Biochemistry, 48(3), 406-412. https://doi.org/10.1016/j.procbio.2013.01.011

Simone, G. (2017). A glyco-competitive assay to demonstrate the stochasticity of fate decisions in Escherichia coli. Process Biochemistry, 53, 61-68. https://doi.org/10.1016/j.procbio.2016.12.007
Tao, W., Xu, Q., Huang, H. and Li, S. (2015). Efficient production of peracetic acid in aqueous solution with cephalosporin-deacetylating acetyl xylan esterase from Bacillus subtilis. Process Biochemistry, 50(12), 2121-2127.https://doi.org/10.1016/ j.procbio.2015.10.009

Vintila, T., Vintila, D., Dragomirescu, M. and Igna, V. (2009). Entrapment of Fluorescent E . coli Cells in Alginate Gel Entraparea Celulelor Fluorescente De E. coli. Lucrări Ştiinţifice Zootehnie Şi Biotehnologii, 42(1), 130-135.

Zeikus, J.G., Jain, M.K. and Elankovan, P. (1999). Biotechnology of succinic acid production and markets for derived industrial products. Applied Microbiology and Biotechnology, 51(5), 545-552. https://doi.org/10.1007/s002530051431

Zhao, J. and Xia, L. (2010). Ethanol production from corn stover hemicellulosic hydrolysate using immobilized recombinant yeast cells. Biochemical Engineering Journal, 49(1), 28-32. https:// doi.org/10.1016/j.bej.2009.11.007

Zhou, Y., Martins, E., Groboillot, A., Champagne, C.P. and Neufeld, R.J. (1998). Spectrophotometric quantification of lactic bacteria in alginate and control of cell release with chitosan coating. Journal of Applied Microbiology, 84, 342-348. https:// doi.org/10.1046/j.1365-2672.1998.00348.x 